DOI: https://doi.org/10.35961/jppmkepri.v1i1.239

\title{
Komunikasi Interpersonal Melalui Daring Dalam Mendukung Pencegahan Penyebaran Virus Covid-19 Pada MAN Bintan
}

\author{
Nova Dwiyanti ${ }^{1 *}$, Afna Fitria Sari ${ }^{2}$, Yozi Rahmadeni ${ }^{3}$, Ningratna Sinta Dewi ${ }^{4}$, \\ Syahrul Rahmat ${ }^{5}$ \\ 1, 2,3,4,5 STAIN Sultan Abdurrahman Kepulauan Riau, Bintan, Kepulauan Riau, 29123, Indonesia \\ * nova_dwiyanti@stainkepri.ac.id
}

\begin{abstract}
Abstrak
Komunikasi tetap bisa terjalin meskipun dalam masa pandemic Covid-19. Dewasa ini, komunikasi daring melalui platform media menjadi solusi yang paling efektif sebagai sarana interaksi satu sama lain meskipun tidak saling bertemu. Komunikasi Interpersonal yaitu Komunikasi tatap muka secara tidak langsung yang berfungsi sangat efektif di sosialisakan kepada siswa/i MAN Bintan. Sehingga dengan diadakan Seminar Komunikasi Interpersonal Daring pada Siswa/I Man Bintan dengan menggunakan aplikasi whatsapp dan zoom meeting ini dapat menerapkan program pemerintah dalam pencegahan Covid 19 agar tetap stay at home dan physical distance.
\end{abstract}

Kata kunci: Daring; komunikasi interpersonal; media.

\begin{abstract}
Communication still can be used even in this Covid-19 situation. Nowadays, virtual communication through any platform become effective as interaction media without meet each other. Interpersonal communication is an indirectly communication for understanding each other personality, more effective to implement for students of MAN Bintan. So, by this Virtual Socialization of Interpersonal Communication for students of MAN Bintan using Whatsapp and Zoom Meeting Application can implement the government programs to prevent Covid-19 in order to stay at home and keep physical distancing.
\end{abstract}

Keywords: Virtual; interpersonal communication; media.

\section{Pendahuluan}

Komunikasi Daring atau merupakan Singkatan Komunikasi Dalam jaringan adalah cara berkomunikasi yang saluran medianya menggunakan internet. Komunikasi ini mempunyai makna yaitu cara Penyampaian Pesan Dari komunikator kepada Komunikan melalui jaringan Internet. 
Seiring dengan perkembangan zaman, komunikasi Daring memiliki kemajuan yang sangat pesat salah satunya adalah Media online yang merupakan media komunikasi yang sudah menjadi primadona dalam kehidupan masyarakat Indonesia dan dunia. perkembangan di seluruh sektor bidang termasuk pendidikan dan dunia hiburan yang semakin lama menjadi semakin semarak.

Masa Pandemi Covid 19 seperti sekarang ini, Media Online sangat bermanfat bagi masyarakat terutama remaja, sebagai langkah social distance dan menjadikan kesibukan tersendiri bagi remaja untuk tetap Berada dirumah serta tidak melewatkan perkembangan berita tentang wabah dan antisipasi penyebarannya. Sehingga masyarakat di tuntut untuk melek terhadap Media dan mampu memfilter isu yang menyimpang. Sehingga tidak selamanya beberapa konten dalam Media online membawa kebaikan sesuai dengan peran dan fungsinya sebagai media massa penyebar informasi. Banyak tayangan dan informasi harus dicermati terlebih dahulu terutama dalam hal memberikan tayangan yang sesuai dengan keadaan yang sebenarnya. Menurut data kominfo di akhir tahun 2016 ada sekitas 800 ribu situs yang terindikasi penyebaran hoax dan ujaran kebencian dan untungnya berita ini bukan berita tentang wabah Covid 19 .

Kondisi seperti ini kami ingin adanya peran siswa MAN Bintan yang notabene dari madrasah Keislaman harus memiliki etika yang baik dalam berkomunikasi tatap muka (Interpersonal) langsung ataupun melaui daring serta menjadi teladan dalam kehidupan nyata maupun bermedia online, dan melakukan social distance agar terhindar dari wabah Corona atau Covid 19 yang sudah pandemi pada masyarakat, sehingga kami perlu mengadakan Seminar "Komunikasi interpersonal melalui daring dalam mendukung pencegahan penyebaran virus covid 19 pada MAN Bintan"

\section{Metode}

Metode pelaksanaan PKM (Pengabdian kepada Masyarakat) dalam penerapan IPTEK adalah kaji tindak partisipasif. Metode ini adalah kegiatan yang banyak melakukan pengambilan bagian, seperti mendengar, berbagi pengalaman, dan pembelajaran dari yang lain. (Learning and Teaching Scotland, 2007:23). Menurut Sudjana (2005:43) partisipatif berarti pengikutsertaan seseorang untuk melakukan sesuatu atau pengambilan bagian dari sesuatu yang harus dilakukan oleh pelakunya. Pembelajaran partisipasif dapat diartikan sebagai upaya pendidik untuk mengikutsertakan peserta didik dalam kegiatan pembelajaran. Pembelajaran partisipsif mengandung arti ikut sertanya peserta didik di dalam program pembelaajran partisipasif. Keikutsertaan peserta didik itu diwujudkan dalam tiga tahaapn kegiatan pembelajaran yaitu perencanaan program, pelaksanaan, dan penilaian kegiatan pembelajaran. Untuk mencapai tujuan tersebut perlu penyadaran masyarakat khususnya kader yang berkenaan dengan permasalahan yang dihadapi, selanjutnya didorong untuk mencari alternatif pemecahan masalah yang lebih efektif melalui pendekatan kaji tindak. Dalam prakteknya, tim PKM sebagai fasilitator dan pelaksana melakukan kegiatan PKM sesuai kesepakan dengan mitra yaitu MAN BINTAN.

Kegiatan Pengabdian dosen kepada masyarakat ini dilakukan dalam tiga tahap, yaitu tahap Persiapan lapangan, pelaksanaan, dan evaluasi.

\section{Hasil dan Pembahasan}

Komunikasi adalah Upaya untuk membuat pendapat/ide, menyatakan perasaan, agar diketahui atau dipahami oleh orang lain dan Kemampuan untuk menyampaikan informasi/pesan dari Komunikator ke Komunikan melalui saluran/media dengan harapan mendapatkan umpan balik. Unsur-unsur yang ada dalam Komunikasi adalah Komunikator, Pesan, Channel/Media, Komunikan dan Respon/Feedback. 
Komunikasi interpersonal secara umum adalah komunikasi antara orang-orang secara tatap muka, masing-masing orang yang terlibat dalam komuniasi tersebut saling mempengaruhi persepsi lawan komunikasinya. Bentuk khusus komunikasi interpersonal ini adalah komunikasi diadik. DeVito berpendapat bahwa komunikasi interpersonal adalah komunikasi yang terjadi diantara dua orang yang telah memiliki hubungan yang jelas, yang terhubungkan dengan beberapa cara. Jadi komunikasi interpersonal misalnya komunikasi yang terjadi antara ibu dengan anak, dokter dengan pasien, dua orang dalam suatu wawancara, dsb. Deddy Mulyana (2005) menyatakan: "komunikasi antarpribadi (interpersonal communication) adalah komunikasi antara orang-orang secara tatap muka, yang memungkinkan setiap pesertanya menangkap reaksi orang lain secara langsung, baik secara verbal ataupun nonverbal.” (Mulyana, 2005:73).

\section{Tahap pertama Persiapan}

Tahap persiapan yaitu pada tahap ini, tim melakukan Pembuatan Proposal kegiatan pengabdian serta pembagian dan pemantapan tim Pelaksana kegiatan memantapkan tugas pokok dan fungsi pada bagian tugas masing - masing.

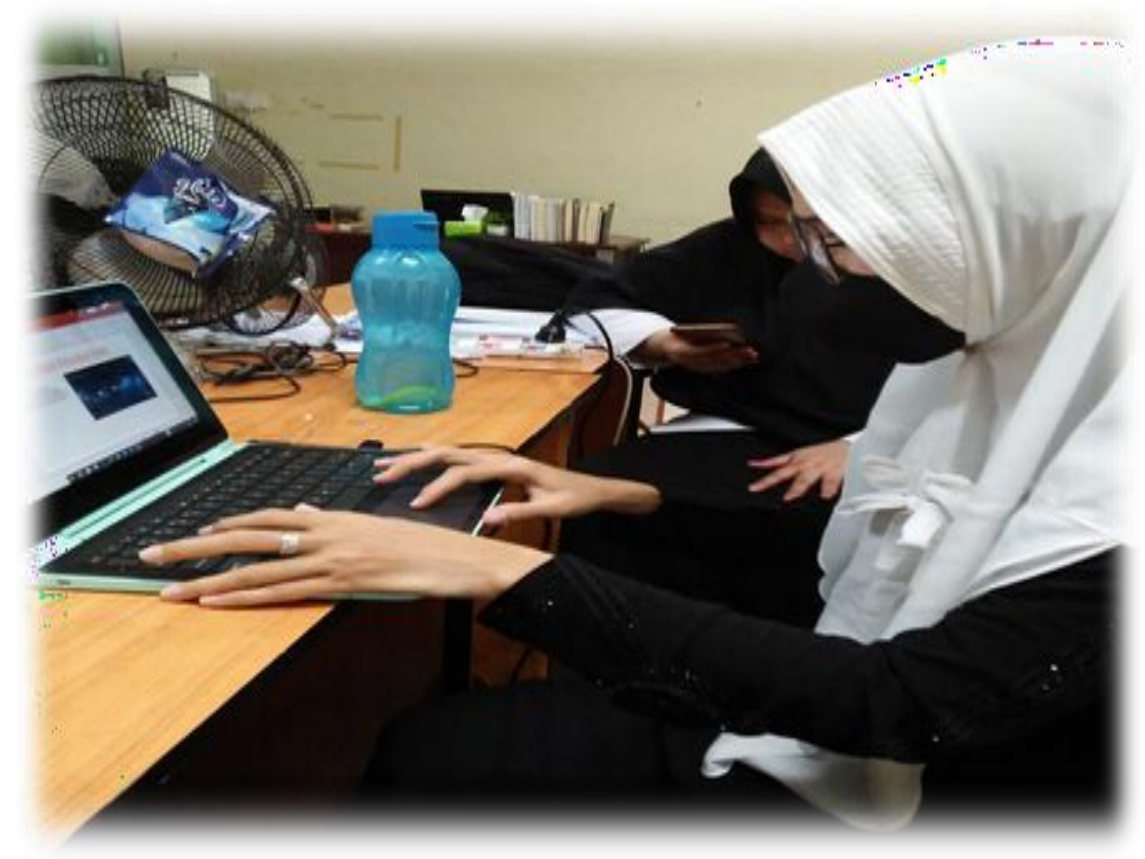

Gambar 1. Pemantapan tim Pengabdian

Pelaksanaan tahap persiapan lapangan kegiatan Pengabdian ini dilakukan pada minggu pertama di bulan april dan di minggu keduanya tim pelaksana melakukan seminar proposal di kampus STAIN Sultan Abdurrahman Kepulauan Riau berguna pemantapan proposal sebelum ke tahap pelaksaan dan dari seminar tersebut mendapatkan masukan dari dua reviewers berupa perbaikan- perbaikan konsep pada saat pelaksaan kegiatan sehingga tersusun hasil akhir proposal untuk melaksanakan kegiatan. Selanjutnya tim membuat pedoman kuesioner berupa google form untuk mengetahui sejauh mana keberhasilan Pengabdian kami kepada Siswa/i Man Bintan.

Survey lapangan ke sekolah Man Bintan untuk melakukan koordinasi Kepada Kepala sekolah dan guru Madrasah Aliyah Negeri Bintan pada tanggal 06 mei 2020, hal ini dilakukan untuk meminta izin dan mendapatkan informasi yang akurat tentang Siswa/i MAN BINTAN salah satunya meminta nomor kontak Whatsapp para Siswa/I dari wali kelas setiap kelas masing-masing. 


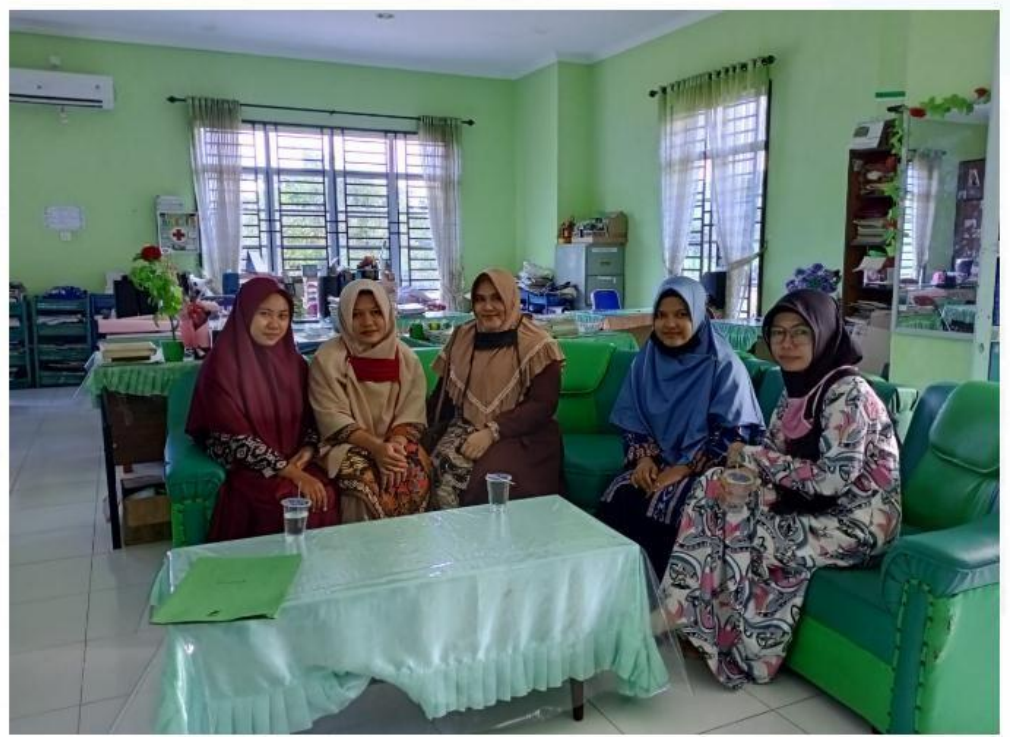

Gambar 2. Koordinasi kepala sekolah dan guru MAN Bintan

Informasi yang didapat dalam survey lapangan ini bahwa dari seluruh jumlah siswa/ I Man Bintan yang mempunyai telepon Pintar hanya 17 Siswa dan merekalah yang mewakili kelas masing-masing untuk menshare terkait Sosialisasi Literasi Digital: Komunikasi Interpersonal melalui daring dalam mendukung Pencegahan Covid-19 pada Siswa/i MAN Bintan.

\section{Tahap Kedua Tahap Pelaksanaan}

Pengabdian Masyarakat ini dilakukan dengan menggunakan media daring, yaitu whatsapp dan zoom pada tanggal 15 Mei 2020 yang diikuti oleh 21 orang peserta. Peserta tersebut adalah perwakilan dari beberapa kelas masing-masing yang jumlah keseluruhan siswa/i MAN Bintan lebih kurang 200 siswa, Sebelum kami melakukan pengabdian yang berbentuk seminar melalui daring, dilakukan pree tes yang berupa angket pertanyaan sederhana dan biodata pribadi siswa.

Angket 1

Angket Mengetahui pengenalan media platform internet

\begin{tabular}{|c|l|}
\hline 1 & Nama \\
\hline 2 & Email \\
\hline 3 & Jenis Kelamin \\
\hline 4 & No WhatsApp \\
\hline 5 & Kelas \\
\hline 6 & Jurusan \\
\hline
\end{tabular}


7 Sejak Kapan Anda Mengenal Media Sosial atau Media Komunikasi Digital Dari manakah anda mengenal Media Sosial Pertama kali

Platform Media Sosial Apa yang anda Miliki. (Boleh memilih lebih dari 1) Apakah Media

Sosial Memberikan Manfaat dalam Kehidupan anda

Apakah dengan adanya Media Sosial dapat menambah wawasan anda tentang Materi

9

Pembelajaran di Sekolah

Apakah Anda Pernah Menggunakan Media Daing dalam Proses Belajar Mengajar (PBM)

10 selama \#dirumahaja Media daring apa yang anda gunakan ketika PBM \#dirumahaja (Boleh di isi lebih dari 1)

Jenis Kelamin

17 responses

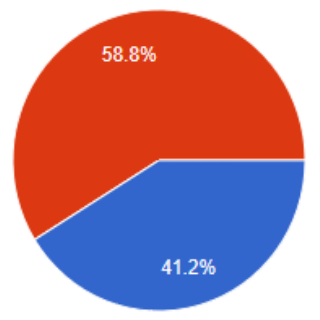

Gambar 3. Diagram Jenis kelamin

Program kegiatan PKM dosen ini berlangsung menggunakan media zoom karena keterbatasan waktu dan kondisi dari 21 orang yang mempunyai telpon pintar atau yang sering disebut HP Android hanya 17 orang siswa yang dapat mengisi kuesioner dan didominasi oleh siswa perempuan

Sejak Kapan Anda Mengenal Media Sosial atau Media Komunikasi Digital?

17 responses

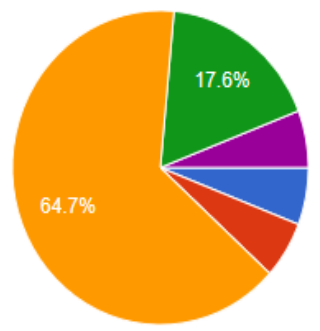

PAUD/TK

$\mathrm{SD} /$ Sederajat

SMP/ Sederajat

SMU/Sederajat

- Lainnya

Gambar 4. Diagram Lingkaran responden

Hasil dari angket yang disebar di awal maka menjelaskan bahwa siswa Man Bintan mengenal media komunikasi digital itu sebagian besar pada ssat menginjak sekolah SMP (64,7\%), dan disusul SMA (17,6\%) 
selebihnya PAUD, SD/ Sederajat dan Lainnya. Dimana media sosial sendiri itu diperkenalkan oleh orangtua $(41.2 \%)$ dan selebihnya dari teman, media massa dan lain sebagainya.

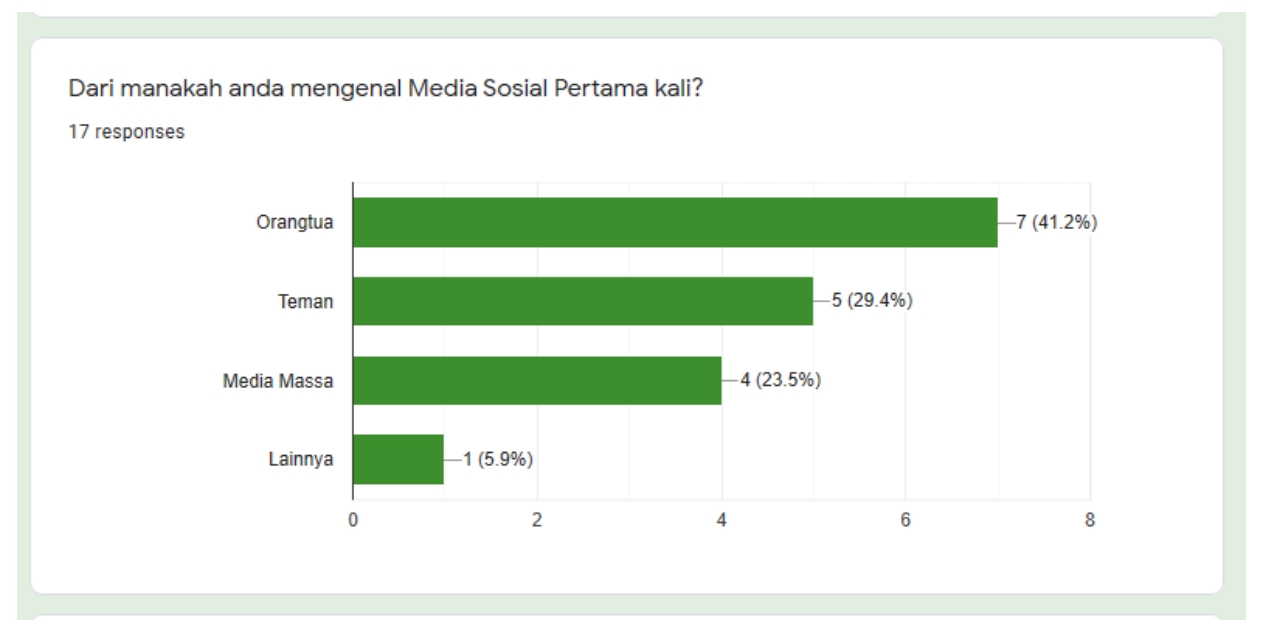

Gambar 5. Diagram Batang

Angket diatas kami dapat diambil kesimpulan mereka sudah pernah menggunakan dan mengenal media social namun mereka belum pernah mengklasifikasi kedalam komunikasi Interpersonal daring. Sehingga pengabdian yang di lakukan oleh prodi komunikasi Penyiaran Islam ini berupa seminar yang menitik beratkan tentang pemahaman komunikasi Interpersonal melalui daring.

"Komunikasi sangat sering dilakukan dan merupakan kebutuhan yang sangat mendasar bagi manusia, karena hampir setiap saat dalam kehidupan di butuhkan berkomunikasi antar individu hingga kelompok. Secara verbal terjadi pada saat seseorang dengan orang lain saling menyampaikan pesan, tetapi apabila seseorang dengan orang lain dalam jarak yang jauh dapat pula dilakukan dengan berbagai cara untuk berkomunikasi satu sama lain. Istilah komunikasi dalam bahasa Inggris yakni communication. Pada dasarnya, secara etimologis kata komunikasi berasal dari bahasa Latin yaitu communis yang bersumber pada kata communis yang berarti "sama", communico, communicatio, atau communicare yang berarti "membuat sama" (to make common). Istilah pertama communis paling sering disebut sebagai asal kata komunikasi, yang merupakan akar dari kata-kata latin lainnya yang mirip. Komunikasi menyarankan bahwa suatu pikiran, suatu makna, atau suatu pesan dianut secara sama" (Deddy Mulyana, 2014:46).

Komunikasi interpersonal daring yang kami lakukan menggunakan flatform media Zoom. Pada awalnya para siswa tidak mengetahui bahwa yang mereka lakukan saat sudah menggunakan zoom adalah berupa komunikasi interpersonal daring. Sehingga pada saat seminar berlangsung narasumber bertanya kepada peserta tentang makna komunikasi namun para peserta menjawab komunikasi hanya sekedar berbicara saja, pada hakikatnya makna komunikasi itu bukan hanya sekedar berbicara. Alasan tersebut menjadikan narasumber memberikan pemahaman dasar berupa makna Komunikasi ,unsur-unsur komunikasi, hambatan-hambatan komunikasi dan komunikasi Interpersonal baik berupa langsung maupun daring. 


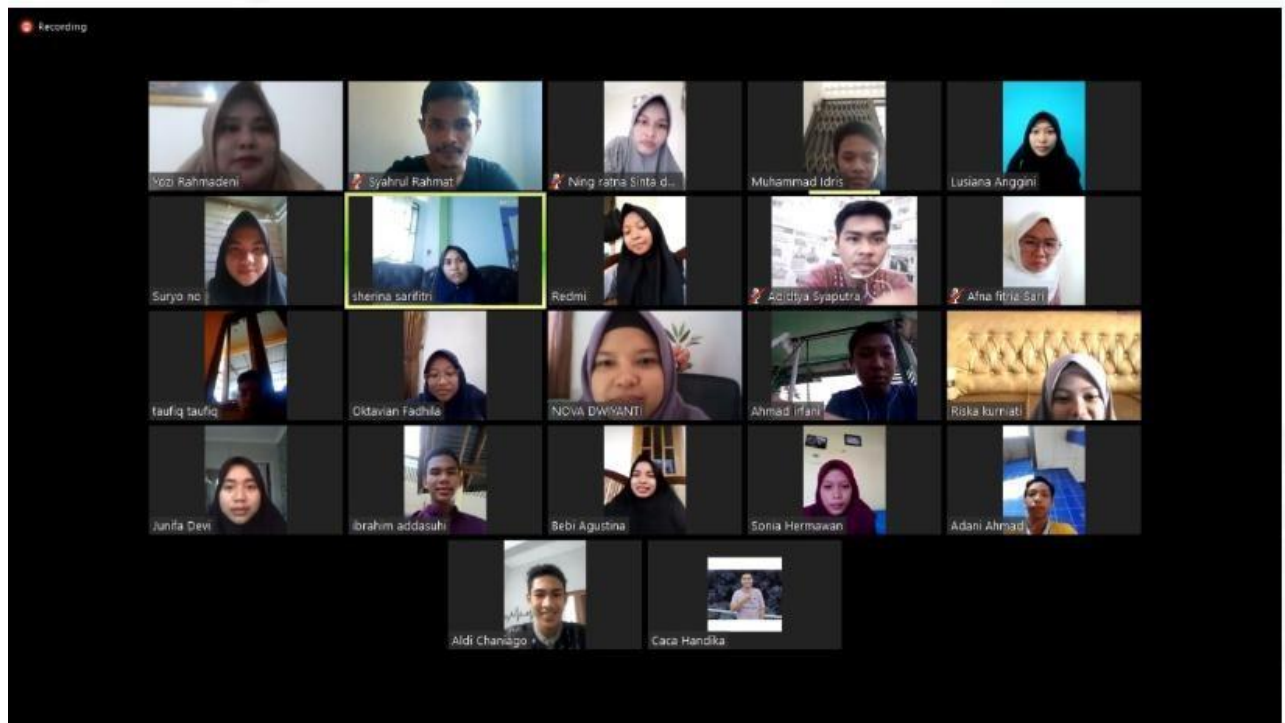

Gambar 6. Kegiatan Sosialisai

Gambar di atas adalah kegiatan sosialisi oleh ketua tim sebagai narasumber seminar dalam mejelaskan materi Komunikasi Interpersonal menggunakan Komunikasi Interpersonal melalui Daring berupa Zoom. Komunikasi Interpersonal daring adalah komunikasi tatap muka secara langsung baik berupa verbal dan non verbal, namun seiring perkembangan pada media komunikasi, komunikasi interpersonal sudah tidak lagi berupa tatap muka secara langsung. Perkembangan media massa dalam istilah komunikasi massa sudah menggeser fungsi komunikasi interpersonal secara tatap muka secara langsung menjadi komunikasi surat elektronik berupa daring.

Komunikasi Interpersonal daring adalah komunikasi tatap muka secara langsung baik berupa verbal dan non verbal, namun seiring perkembangan pada media komunikasi, komunikasi interpersonal sudah tidak lagi berupa tatap muka secara langsung. Perkembangan media massa dalam istilah komunikasi massa sudah menggeser fungsi komunikasi interpersonal secara tatap muka secara langsung menjadi komunikasi surat elektronik berupa daring.

"DeVito menyatakan dalam buku komunikasi Psikologi Jalaluddin Rakhmat (2005: 15) 'The five major purposes of interpersonal communication are to learn about self, others, and the world; to relate to others and to form relationship; to influence or control the attitudes and behaviours of others; to play or enjoy oneself; to help others.' (komunikasi interpersonal adalah komunikasi untuk belajar diri sendiri, orang lain, bahkan dunia, melalui komunikasi interpersonal kita dapat mengetahui siapa dan bagaimana orang lain dan dapat mengetahui pendapat orang lain tentang diri kita sendiri). Kita semakin mengenal diri kita sendiri, orang lain serta dapat mengenal lingkungan kita sendiri serta dunia. Suksesnya komunikasi interpersonal sangat tergantung pada kualitas konsep diri seseorang."

Masa pandemic ini menggunakan media daring berupa Komunikasi Interpersonal adalah solusi mengurangi contact langsung namun tetap bisa berinteraksi baik secara personal maupun secara kelompok melalui media masa yang berfungsi agar para siswa/i Man Bintan mengisi kegiatan dirumah dengan memanfaatkan komunikasi daring yang berupa whats upp dan Zoom Meeting, Pemahaman dasar-dasar tentang komunikasi ini akan menjadi bekal mereka untuk lebih memahami makna sesungguhnya komunikasi 
sehingga kedepannya mereka tidak cangggung dan asing lagi tentang makna Komunikasi serta tidak terjadi lagi perbedaan persepsi karena minimnya pengetahuan tentang makna komunikasi.

\section{Tahap Ketiga yaitu Tahap Evaluasi}

Tahapan Evaluasi kami melihat keberhasilanl dari kegiatan PKM dosen. Tahapan ini pengevaluasiannya adalah bahwa para peserta PKm yaitu siswa/i MAn Bintan mengerti penggunaan Komunikasi Interpersonal berupa whats App dan zoom.

Angket 2

\section{Evaluasi Pemahaman Siswa MAN Bintan setelah melakukan Webinar}

\begin{tabular}{|c|l||}
\hline 1 & Nama \\
\hline 2 & Apakah Anda dapat Memahami Materi yang diberikan Pemateri pada Saat Sosialisasi Daring \\
\hline 3 & Apakah Sosialisasi ini memberikan pemahaman tentang bagaimana penggunaan Media Daring \\
\hline 4 & $\begin{array}{l}\text { Apakah Komunikasi melalui media daring yang disampaikan antara lawan bicara dapat dipahami } \\
\text { satu sama lain }\end{array}$ \\
\hline 5 & Apakah Media Daring dapat Mendukung Materi Pembelajaran dengan Baik \\
\hline 6 & $\begin{array}{l}\text { Seberapa Efektifkah Media Daring Sebagai Proses Belajar Mengajar (PBM) selama Social } \\
\text { Distancing }\end{array}$ \\
\hline 7 & $\begin{array}{l}\text { Bagaimana menurut anda Pembelajaran yang diberikan melalui Media daring sebagai pengganti } \\
\text { PBM di Sekolah selama Pandemi Virus Covid -19 }\end{array}$ \\
\hline
\end{tabular}

Komunikasi Daring atau dalam bahasa yang lebih trendy adalah Sosial media dengan menggunakan komunikasi Interpersonal yang berupa platform media seperti: whatsapp, skype, youtube dan sebagainya ternyata sudah mereka gunakan sebelum mereka menggunakan zoom dapat kita lihat pada digram dibawah ini

Platform Media Sosial Apa yang anda Miliki? (Boleh memilih lebih dari 1)

17 responses

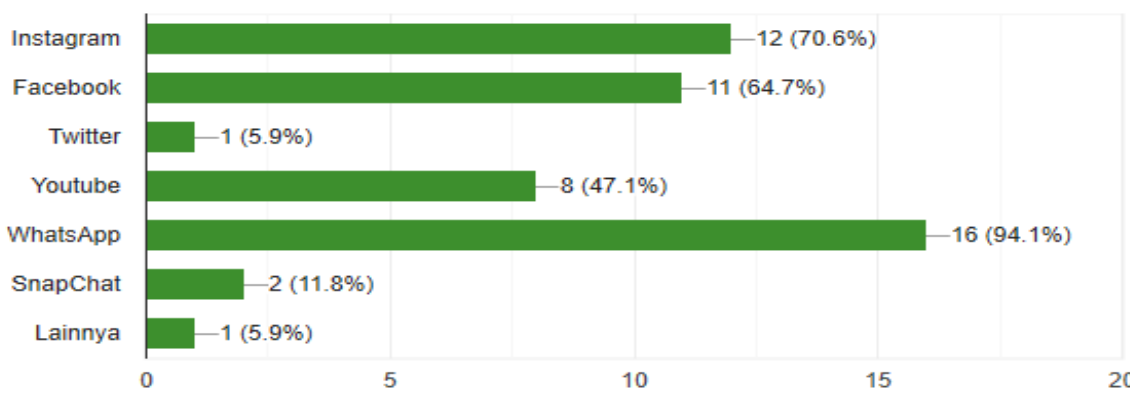

Gambar 7. Diagram Sosial Media yang dimiliki Siswa 
Dari 21 Responden dan yang mengisi kuesioner hanya 17 Responden yang mengisi kuesioner hampir dari seluruhnya pernah menggunakan komunikasi Interpersonal Daring dan bahkan mereka menggunakan platform media lebih dari satu.

Pra pelaksaan seminar pengabdian masyarakat, siswa Man Bintan telah menggunakan media pembelajaran daring, namun bukan zoom, melainkan google class room. Dimana kita ketahui google class room tersebut tidak memiliki feedback secara langsung dalam berkomunikasi, karena google class room adalah media daring yang berakseskan komunikasi digital teks. Maka dari itu kami dari Prodi Komunikasi Penyiaran Islam memperkenalkan media komunikasi secara langsung (tatap muka) atau dalam dunia ilmu komunikasi yang dikenal dengan komunikasi interpersonal.

Tergabung dan masuk dalam Seminar tersebut menandakan bahwa siswa/i MAN Bintan sudah bisa memakai komunikasi Interpersonal daring yang mereka lakukan secara langsung menggunakan media Zoom. Selain daripada itu kami juga menyebar kuesioner berupa angket untuk mengetahui tingkat Pemahaman dari para peserta tentang materi yang di sampaikan Narasumber.

\section{Apakah Anda dapat Memahami Materi yang diberikan Pemateri pada Saat Sosialisasi Daring?}

15 responses
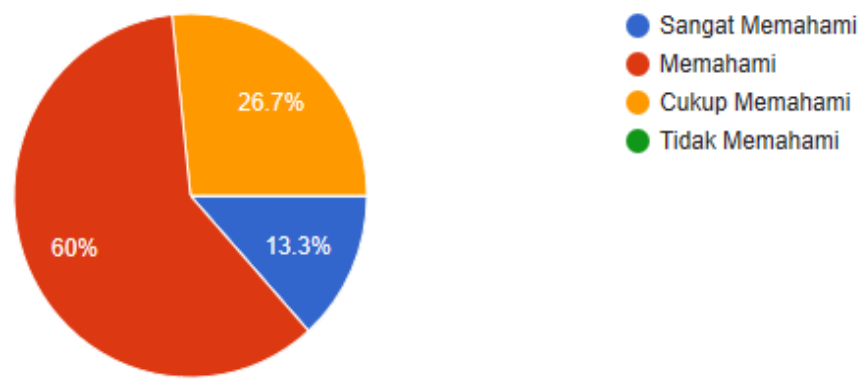

Gambar 8. Tingkat Pemahaman Peserta Sosialisasi.

Dari gambar diagram diatas $60 \%$ Peserta yang memahami materi pembelajaran dan 13,3\% Peserta Sangat memahami sedangkan $26 \%$ cukup memahami dan $0 \%$ tanda hijau bahwa mereka tidak memahami.

Komunikasi Interpersonal daring adalah komunikasi tatap muka yang menitik beratkan komunikasi berupa tatap muka langsung namun saat masa pandemic ini agar pada para siswa/ I Man bintan agar para siswa/I Man Bintan mengisi kegiatan dirumah dengan memanfaatkan komunikasi daring yang berupa whatsapp dan Zoom Meeting, Penggunaan platform media tersebut maka diharapkan para siswa MAN Bintan melakukan kegiatan sosialnya tidak secara langsung sehingga dapat menjadi antisipasi pencegahan penyebaran penularaan covid19 dan dapat di menerapkan protokuler kesehtan pemerintah anatara lain social distance dan healt distance.

Adapun kuesioner ini memiliki 7 pernyataan. Hasil respons yang diberikan oleh siswa dapat dilihat sebagai berikut 
Tabel 1.

\section{Jadwal Pelaksanaan Kegiatan}

\begin{tabular}{|c|c|c|}
\hline Pertemuan & Hari, Tanggal & Materi \\
\hline I & Rabu, 06 Mei 2020 & $\begin{array}{c}\text { koordinasi Kepada Kepala sekolah dan guru Madrasah Aliyah Negeri } \\
\text { Bintan }\end{array}$ \\
\hline II & Jumat, 15 Mei 2020 & Realisasi Pengabdian \\
\hline
\end{tabular}

\section{Kesimpulan} bahwa:

Dari kegiatan pengabdian Masyarakat ini yang berupa seminar ini, kami mengambil kesimpulan

1. Siswa/i Man Bintan sudah mampu mengaplikasikan Media Komunikasi melalui daring pada mas Pandemi Covid 19 terlihat dari diagram Lingkaran yang berupa pertanyaan kuesioner yang di sebar bahwa o\% yang tidak memahami materi

2. Siswa/i MAN Bintan sudah mampu memahami dasar Komunikasi dan komunikasi Interpersonal baik secara langsung maupun daring

\section{Saran}

Diharapkan kedepan adanya seminar berkelanjutan untuk pengenalan media pembelajaran zoom kepada guru-guru MAN BINTAN untuk dapat menggunakan media zoom dalam pembelajaran nantinya untuk mempermudah pembelajaran ketika adanya social distancing.

\section{Ucapan Terimakasih}

Terimakasih pengabdi ucapkan kepada:

1. Seluruh anggota P3M Stain Sultan Abdurrahman Kepulauan Riau

2. Reviwers atas masukaannya kepada tim penulis

3. Kepala Sekolah MAN Bintan atas kerjasamanya dan koordinasinya kepada tim penulis sehingga dapat melaksanakan PKM Dosen dengan maksimal di MAN Bintan

4. Siswa/I MAN Bintan yang telah berkontribusi dalam pelaksanaan Webinar.

5. Seluruh pihak yang telah membantu proses pengabdian masyarakat

\section{Referensi}

Ali Sadikin*, Afreni Hamidah (2020). Pembelajaran Daring di Tengah Wabah Covid-19 (Online Learning in the Middle of the Covid-19 Pandemic). BIODIK: Jurnal Ilmiah Pendidikan Biologi. Program Studi Pendidikan Biologi FKIP Universitas Jambi. Volume 6, Nomor 02, Hal. 214-224. https://onlinejournal.unja.ac.id/biodik

APJII (2016). Profil Penggunaan Internet Indonesia (edisi pertama). Jakarta :APJII Learning Teaching

Scotland. (2007). Participative ang Learning. Scotland: Save the Childern.h.

Mulyana, Deddy. 2014. Ilmu Komunikasi Suatu Pengantar.PT. Remaja Rosdakarya. Bandung Rakhmat, Jalaluddin, 2005,. Psikologi Komunikasi, pt. Remaja Rosdakarya, Bandung. 
Mujibul Hakim1 , Aria Mulyapradana (2020). Pengaruh Penggunaan Media Daring dan Motivasi Belajar Terhadap Kepuasan Mahasiswa Pada Saat Pandemi Covid-19. Widya Cipta : Jurnal Sekretari dan Manajemen ITS NU Pekalongan. Volume 4. Hal 154-160. https://ejournal.bsi.ac.id/ejurnal/index.php/ widyacipta

Oktafia Ika Handarini, Siti Sri Wulandari (2020). Pembelajaran Daring Sebagai Upaya Study From Home (SFH) Selama Pandemi Covid 19. Jurnal Pendidikan Administrasi Perkantoran (JPAP), Universitas Negeri Surabaya. Volume 8, Nomor 3. Hal 496-503. https://journal.unesa.ac.id/index.php/jpap

Sudjana. (2005). Metoda dan Teknik Pembelajaran Partisipasif. Bandung: Fallah Production,h. 